\title{
Additions to the lichen flora of Assam with special reference to Astrothelium alboverrucoides, a new record to India
}

\author{
Daimari $\mathbf{R}^{1 *}$, Islary $\mathbf{P}^{1}$, Brahma $S^{1}$, Basumatary $\mathbf{S}^{1}$, Goswami JP', Nayaka $\mathbf{S}^{2}$ and \\ Joseph $\mathbf{S}^{2}$
}

${ }^{1}$ Department of Botany, Bodoland University, Kokrajhar, Assam-783370, India

${ }^{2}$ Lichenology Laboratory, CSIR-National Botanical Research Institute, Lucknow-226001, India

Daimari R, Islary P, Brahma S, Basumatary S, Goswami JP, Nayaka S, Joseph S 2021 - Additions to the lichen flora of Assam with special reference to Astrothelium alboverrucoides, a new record to India. Studies in fungi 6(1), 342-351, Doi 10.5943/sif/6/1/25

\begin{abstract}
The present study enumerates the diversity of corticolous lichens from Kokrajhar district of Assam state. The study records 54 species of lichens belonging to 21 genera and 14 families. Majority of the species are crustose (44 species) and 10 are foliose. One of the species, Astrothelium alboverrucoides is a new record to India while five species viz.,Graphis sayeri, Hemithecium croceum, Malmidea piperis, Ocellularia allosporoides and Porina belanospora are new additions to the lichen biota of Assam. Among the species, nine are endemic to India. Graphidaceae is the dominant family and Dirinaria consimilis is frequently found in all the study sites. This indicates its scope for future applications in other studies related to lichens in the region.
\end{abstract}

Keywords - Corticolous - Enumeration - Ultapani Forest range - University campus

\section{Introduction}

About 25,000 species of lichens have been reported globally (Soundararajan et al. 2019), of which more than 2902 lichens have been reported from India (Sinha \& Ram 2020). The eastern Himalaya is one of the richest lichenogeographical regions of India. Singh et al. (2018) reported 1047 species, one sub-species and four varieties. Most of the species are crustose (592 species) and 321 are foliose, 125 are fructicose, nine are squamulose under 212 genera and 63 families. Lichens are a symbiotic association of two organisms viz. an alga and a fungus, and are one of the most widely distributed organisms. Recently with the discovery of about 1050 secondary metabolites (StockerWörgötter 2008), its applications as potential antimicrobial, antioxidant, anticancer activity (Zambare \& Christopher 2012, Shivanna \& Garampalli 2014, 2016, Kekuda et al. 2017) are gaining much elevation.

Being a biodiversity hotspot, Assam has always been a region of attraction. It is rich in floral as well as faunal diversity and it comes under the northeastern Indian biogeographic zone. The region is suitable for the colonization of diverse organisms including lichen. In spite of being rich in biodiversity, the exploratory work on lichens of Assam is limited. The study of lichen in Assam was first initiated by Scottish lichenologist Stirton (1881) followed by Santesson 1952, Awasthi \& Singh 1973. Later on, the lichenological work was extended by Pant \& Upreti 1993, Rout et al. 2005, 2010, Gupta \& Sinha 2011, 2016, Sinha et al. 2013, Daimari et al. 2014. Recently, Gupta \& Sinha (2018) reported 300 species of lichens from various parts of Assam of which eight lichen species have been reported from Kokrajhar district for the first time. However, greater portion of the district remain 
unexplored. Therefore, the present study was taken up with an aim to explore and enumerate the lichen diversity of Kokrajhar district.

Kokrajhar, one of the 34 districts of Assam state is the gateway to the northeastern part of India. The district is located in the foothills of Bhutan on its northern side and lies between $26^{\circ} 18^{\prime}-26^{\circ} 54^{\prime}$ $\mathrm{N}$ latitude and $89^{\circ} 46^{\prime}-90^{\circ} 58^{\prime} \mathrm{E}$ longitude. It has an average elevation of $38 \mathrm{~m}$ and enjoys sub-tropical monsoon climate with high levels of humidity ( $c a 85 \%)$ and heavy rainfall (3139 mm). Majority of the land is covered by agricultural fields. Forest is one of the most prominent features of Kokrajhar district. The forest cover is mainly confined to the northern part of the district along the foothills of Bhutan. Presence of the foothill makes the region ecologically interesting with varied climate, edaphic and altitudinal gradients.

\section{Materials \& methods}

\section{Sampling sites}

Four sites viz. Bodoland University Campus (BU), Chakrashila Wildlife Sanctuary, Pakriguri (residential area) and Ultapani Forest Range (UFR) were selected for the present study, within Kokrajhar district (Fig.1). The vegetation of Ultapani in particular is very interesting with dense vegetation that includes semi-evergreen and moist deciduous forest and also houses various species of orchids. During the month of March and April the forest looks exceptionally beautiful as innumerable butterflies flourish it and so is also called 'Haven of Butterfly'. Chakrashila Wildlife sanctuary on the other hand is mostly dominated by Shorea robusta and is famous for golden langur.

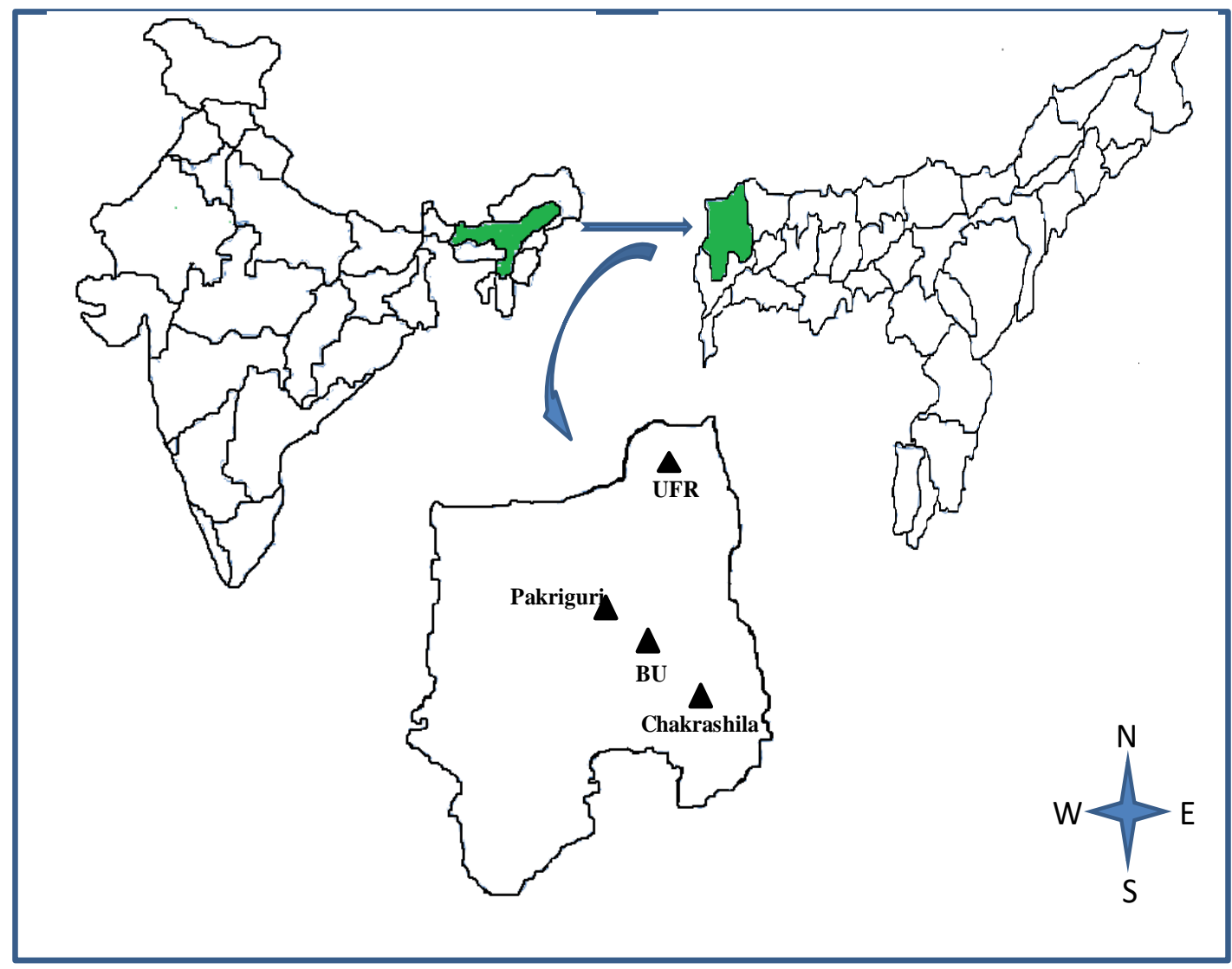

Fig. 1 - Map showing the locations of collection sites in Kokrajhar District of Assam

\section{Collection and identification of samples}

Lichen samples were collected during the year 2017 and 2018 from the bark of trees. Samples were then air dried and sorted. Identification of the lichen specimens were done morphologically, anatomically and chemically. Morphological characters were examined using stereo zoom 
microscope (Leica EZ4W) and anatomical details of the thallus and fruiting bodies were studied in free hand section using water as mounting medium under compound microscope (Leica DM750). Chemical spot test was performed using K, C, KC, P reagents (Nayaka 2014). TLC was carried out to identify the lichen substances using standard solvent system, Toluene (180): 1, 4- Dioxane (60): Acetic acid (8) (Orange et al. 2001). Recent literatures (Awasthi 1991, 2007, Lücking et al. 2009, Aptroot 2012, Aptroot \& Lücking 2016, Gupta et al. 2016, Joshi et al. 2018) were referred for identification of the lichen species. The specimens are deposited in the Department of Botany, Bodoland University (BU) Kokrajhar, Assam. The faces of fungi numbers were registered as described in Jayasiri et al. (2015).

\section{Results}

From the present study, 54 species of lichens belonging to 21 genera and 14 families are reported (Table 1). Majority of the species are crustose (44 species) and 10 foliose (Fig. 2). Graphidaceae is the dominant family with five genera and 26 species followed by Porinaceae and Caliciaceae with 5 species each. Dirinaria consimilis is frequently found in all the four sites showing its wide distribution.

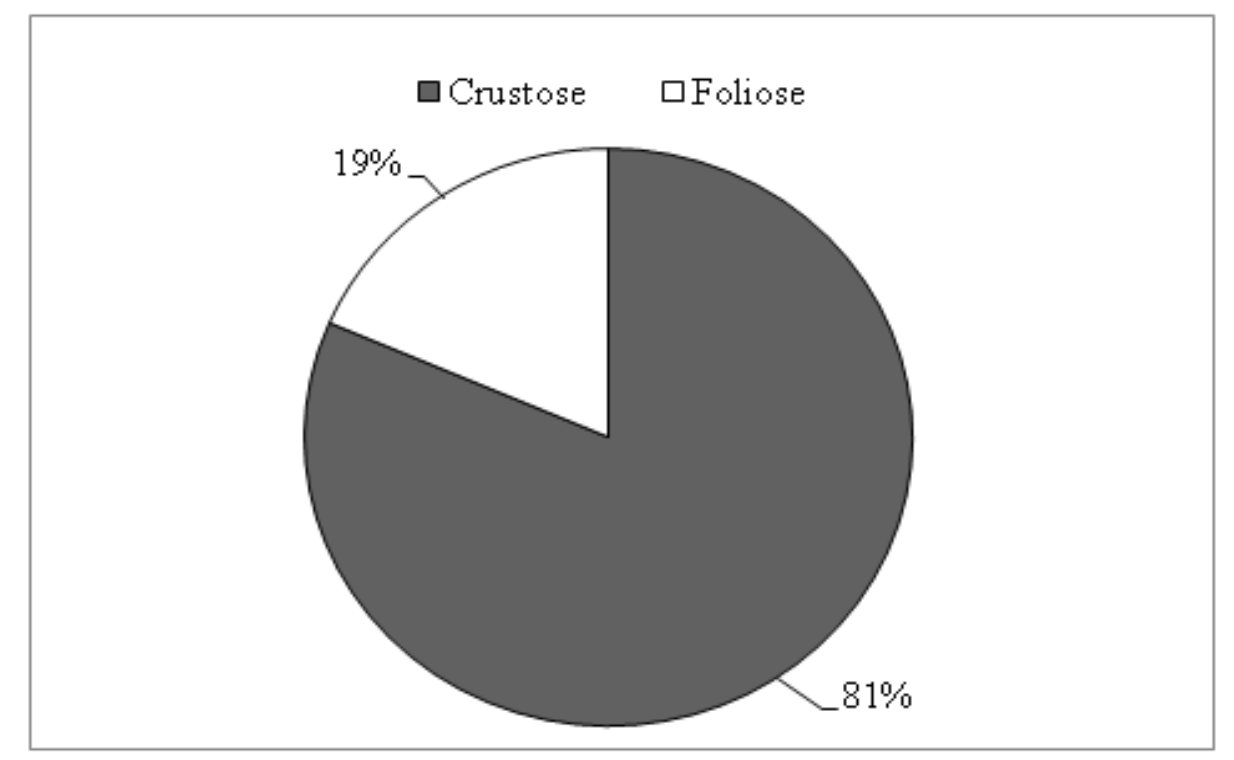

Fig. 2 - Representation of the growth form

Table1 List of lichen species with their growth form, family and distribution in the study sites

\begin{tabular}{|c|c|c|c|c|c|c|c|}
\hline \multirow[t]{2}{*}{ Sl.no. } & \multirow[t]{2}{*}{ Name of species } & \multirow[t]{2}{*}{ GF } & \multirow[t]{2}{*}{ Family } & \multicolumn{4}{|c|}{ Study sites } \\
\hline & & & & 1 & 2 & 3 & 4 \\
\hline 1 & Anthracothecium macrosporum (Hepp) Müll. Arg. & $\mathrm{C}$ & Pyrenulaceae & - & + & - & - \\
\hline 2 & Arthonia dispersula $\mathrm{Nyl}$. & $\mathrm{C}$ & Arthoniaceae & + & - & - & - \\
\hline 3 & A. tumidula (Ach.) Ach. & $\mathrm{C}$ & Arthoniaceae & + & - & + & - \\
\hline 4 & Astrothelium alboverrucoides Aptroot & $\mathrm{C}$ & Trypetheliaceae & - & + & - & - \\
\hline 5 & Bacidia medialis (Tuck.) Zahlbr. & $\mathrm{C}$ & Bacidiaceae & + & - & - & - \\
\hline 6 & Diorygma hieroglyphicum (Pers.) Staiger \& Kalb & $\mathrm{C}$ & Graphidaceae & + & - & - & - \\
\hline 7 & Dirinaria aegialita (Afzel. ex Ach.) B.J. Moore & $\mathrm{F}$ & Caliciaceae & + & + & + & - \\
\hline 8 & D. applanata (Fée) D.D. Awasthi & $\mathrm{F}$ & Caliciaceae & - & - & - & + \\
\hline 9 & D. consimilis (Stirt.) D.D. Awasthi & $\mathrm{F}$ & Caliciaceae & + & + & + & + \\
\hline 10 & Graphis alboglaucescens Adaw. \& Makhija & $\mathrm{C}$ & Graphidaceae & - & + & - & - \\
\hline 11 & G. alpestris (Zahlbr.) Staiger & $\mathrm{C}$ & Graphidaceae & + & - & - & - \\
\hline 12 & G. arecae Vain. & $\mathrm{C}$ & Graphidaceae & - & - & - & + \\
\hline 13 & ${ }^{\circledR}$ G. capillacea Stirt. & $\mathrm{C}$ & Graphidaceae & - & - & - & + \\
\hline
\end{tabular}


Table 1 Continued.

\begin{tabular}{|c|c|c|c|c|c|c|c|}
\hline \multirow[t]{2}{*}{ Sl.no. } & \multirow[t]{2}{*}{ Name of species } & \multirow[t]{2}{*}{ GF } & \multirow[t]{2}{*}{ Family } & \multicolumn{4}{|c|}{ Study sites } \\
\hline & & & & 1 & 2 & 3 & 4 \\
\hline 14 & ${ }^{\circledR}$ G. chlorotica A. Massal. & $\mathrm{C}$ & Graphidaceae & + & - & - & - \\
\hline 15 & G. crebra Vain. & $\mathrm{C}$ & Graphidaceae & - & - & - & + \\
\hline 16 & G. dendrogramma Nyl. & $\mathrm{C}$ & Graphidaceae & - & - & - & + \\
\hline 17 & ${ }^{\circledR}$ G. distincta Makhija \& Adaw. & $\mathrm{C}$ & Graphidaceae & + & - & - & - \\
\hline 18 & G. elegantula Zahlbr. & $\mathrm{C}$ & Graphidaceae & + & - & - & - \\
\hline 19 & G. epimelaena Müll. Arg. & $\mathrm{C}$ & Graphidaceae & + & - & - & - \\
\hline 20 & G. glaucescens Fée & $\mathrm{C}$ & Graphidaceae & - & - & - & + \\
\hline 21 & ${ }^{\circledR}$ G. intermediella Stirt. & $\mathrm{C}$ & Graphidaceae & - & - & - & + \\
\hline 22 & G. pinicola Zahlbr. & $\mathrm{C}$ & Graphidaceae & + & - & - & - \\
\hline 23 & G. pyrrhocheiloides Zahlbr. & $\mathrm{C}$ & Graphidaceae & - & - & - & + \\
\hline 24 & G. renschiana (Müll. Arg.) Stizenb. & $\mathrm{C}$ & Graphidaceae & - & + & - & - \\
\hline 25 & G. sayeri Müll. Arg. & $\mathrm{C}$ & Graphidaceae & - & - & - & + \\
\hline 26 & G. scripta (L.) Ach. & $\mathrm{C}$ & Graphidaceae & - & + & - & - \\
\hline 27 & ${ }^{\circledR}$ G. subasahinae Nagarkar \& Patw. & $\mathrm{C}$ & Graphidaceae & - & + & - & - \\
\hline 28 & G. sundarbanensis Jagad.Ram \& G.P. Sinha & $\mathrm{C}$ & Graphidaceae & - & - & - & + \\
\hline 29 & G. xanthospora Müll. Arg. & $\mathrm{C}$ & Graphidaceae & - & - & - & + \\
\hline 30 & ${ }^{\circledR}$ Hemithecium croceum Makhija \& Adaw. & $\mathrm{C}$ & Graphidaceae & - & + & + & - \\
\hline 31 & Herpothallon philippinum (Vain.) Aptroot \& Lücking & $\mathrm{C}$ & Arthoniaceae & - & - & + & - \\
\hline 32 & Heterodermia diademata (Taylor) D.D. Awasthi & $\mathrm{F}$ & Physciaceae & - & + & + & - \\
\hline 33 & H. speciosa (Wulfen) Trevis. & $\mathrm{F}$ & Physciaceae & - & + & - & - \\
\hline 34 & Lecanora tropica Zahlbr. & $\mathrm{C}$ & Lecanoraceae & - & - & + & - \\
\hline 35 & Letrouitia domingensis (Pers.) Hafellner \& Bellem. & $\mathrm{C}$ & Letrouitiaceae & + & - & - & - \\
\hline 36 & $\begin{array}{l}\text { Malmidea piperis (Spreng.) Kalb, Rivas Plata \& } \\
\text { Lumbsch }\end{array}$ & $\mathrm{C}$ & Malmideaceae & - & - & + & - \\
\hline 37 & Ocellularia allosporoides (Nyl.) Patw. \& Kulk. & $\mathrm{C}$ & Thelotremataceae & - & + & + & - \\
\hline 38 & Parmotrema saccatilobum (Taylor) Hale & $\mathrm{F}$ & Parmeliaceae & - & - & - & + \\
\hline 39 & P. tinctorum (Despr. ex Nyl.) Hale & $\mathrm{F}$ & Parmeliaceae & - & + & + & - \\
\hline 40 & P. tsavoense (Krog \& Swinscow) Krog \& Swinscow & $\mathrm{F}$ & Parmeliaceae & - & - & + & - \\
\hline 41 & Pertusaria quassiae (Fée) Nyl. & $\mathrm{C}$ & Pertusariaceae & - & - & + & - \\
\hline 42 & ${ }^{\circledR}$ Phaeographis extrusula (Stirt.) Zahlbr. & $\mathrm{C}$ & Graphidaceae & + & - & - & - \\
\hline 43 & ${ }^{\circledR}$ P. submarcescens (Leight.) Zahlbr. & $\mathrm{C}$ & Graphidaceae & + & - & - & - \\
\hline 44 & Porina belanospora (Nyl.) Müll. Arg. & $\mathrm{C}$ & Porinaceae & + & - & - & + \\
\hline 45 & P. interestes (Nyl.) Harm. & $\mathrm{C}$ & Porinaceae & - & - & - & + \\
\hline 46 & P. internigrans (Nyl.) Müll. Arg. & $\mathrm{C}$ & Porinaceae & - & + & - & - \\
\hline 47 & P. mastoidea Fée & $\mathrm{C}$ & Porinaceae & - & + & + & - \\
\hline 48 & ${ }^{\circledR}$ P. subhibernica Upreti & $\mathrm{C}$ & Porinaceae & + & - & - & - \\
\hline 49 & Pyrenula macrospora (Degel.) Coppins \& P. James & $\mathrm{C}$ & Pyrenulaceae & + & - & - & - \\
\hline 50 & P. subelliptica (Tuck.) R.C. Harris & $\mathrm{C}$ & Pyrenulaceae & + & - & - & - \\
\hline 51 & Pyxine cocoes (Sw.) Nyl. & $\mathrm{F}$ & Caliciaceae & - & - & - & + \\
\hline 52 & P. reticulata (Vain.) Vain. & $\mathrm{F}$ & Caliciaceae & - & - & - & + \\
\hline 53 & Sarcographa glyphiza (Nyl.) Kr.P. Singh \& G.P Sinha & $\mathrm{C}$ & Graphidaceae & - & - & + & - \\
\hline 54 & S. labyrinthica (Ach.) Müll. Arg. & $\mathrm{C}$ & Graphidaceae & - & - & + & \\
\hline
\end{tabular}

Note: GF = Growth form, C = Crustose, F = Foliose, "_" = Absent, " $+"=$ Present

Study sites: 1. Chakrashila Wildlife Sanctuary, 2. Ultapani Forest Range, 3. Bodoland University Campus,

4. Pakriguri, Residential area; ${ }^{\circledR}$ Endemic to India

\section{Enumeration of the newly recorded species}

Astrothelium alboverrucoides Aptroot, Lichenologist 48(6): 611, 2016

Fig. 3

Index Fungorum number: IF815207; Faces of fungi number: FoF10256

Thallus crustose, corticolous, corticate, smooth somewhat shiny, continuous, yellowish to olivaceous. Ascomata globose, mostly single, with often constricted base. Ostiole apical, not fused, pointed, ochraceous to brown. Hymenium inspersed with oil globules. Asci 4-spored, ascospores hyaline, muriform, ellipsoid, 122-131 x 27-29 $\mu \mathrm{m}$. 
Chemistry - not defined but light grey spot at Rf Class 4 .

Ecology - The species is found growing on the bark of a tree in Ultapani Forest Range.

Distribution - Indonesia.

Species examined - INDIA: Assam, Kokrajhar district, Ultapani Forest Range, on the bark of a tree, 23/02/2017, S. Basumatary, P. Islary \& R. Daimari, 2017-0033, Department of Botany, (BU) Kokrajhar, Assam.

Comment - New record to India.

Graphis sayeri Müll. Arg., Flora (Regensburg) 70(25): 401, 1887

Fig. 4

Thallus crustose, corticolous, corticated, disc concealed, lirellae variable, labia white pruinose, immersed to erumpent with apically thin thalline margin, elongate and irregularly branched (caesiella-morph). Labia entire, excipulum apically carbonised, hymenium clear. Ascospores hyaline, transversely 6-9 septate, 36-40 × 6-7 $\mu \mathrm{m}$.

Chemistry - No lichen substances detected by TLC.

Ecology - The species is found growing on the bark of Ficus hispida in a residential area.

Distribution - India (Uttarakhand), Australia, Pantropical.

Species examined - INDIA: Assam, Kokrajhar district, Pakriguri, on Ficus hispida, 04/07/2018, P. Islary \& S. Brahma, 2018-0065, Department of Botany, (BU) Kokrajhar, Assam.

Comment - New record to Assam

Hemithecium croceum Makhija \& Adaw., Mycotaxon 91: 348, 2005

Fig. 5

Thallus crustose, corticolous, greenish with white tinge to greyish green, rough, cracked, delimited by a thin black hypothallus. Ascomata lirelline, simple to irregularly branched, scattered, immersed to semi-emergent, acute to obtuse ends, disc narrow, slit like, orange red, epruinose. Exciple present below, entire, non-carbonized, yellowish to woody brown, laterally convergent, covered by a thalline exciple till top. Hymenium hyaline, clear, I-, epithecium thin, brown, K-, paraphysis simple, long, thick, unbranched. Asci 6-spored, ascospores hyaline, transversely 8-9 septate, ellipsoidal, 30-49 x 4-6 $\mu \mathrm{m}$, I+ blue.

Chemistry - Stictic acid, cryptostictic and constictic acid.

Ecology - The species is found growing on the bark of a tree in the University campus and on the bark of Bombax sp. in Ultapani Forest Range.

Distribution - India (Andaman and Nicobar Island).

Species examined - INDIA: Assam, Kokrajhar district, Ultapani Forest Range, on Bombax sp., 23/02/2017, S. Basumatary, P. Islary \& R. Daimari, 2017-0023, BUH and on the bark of a tree, 12/04/2018, J. P. Goswami, 2018-0047, Department of Botany, (BU) Kokrajhar, Assam.

Comment - New record to Assam and endemic to India.

Malmidea piperis (Spreng.) Kalb, Rivas Plata \& Lumbsch, Bibliotheca Lichenologica 106: 165, 2011

Fig. 6

Thallus crustose, corticolous, greenish grey, smooth, apothecia without thalline excipulum, margin lacking medullary layer, medulla $\mathrm{K}+$ orange, hypothecium dark brown to brown black. Asci 8-spored, ascospores hyaline, simple, 13-14 x 5-6 $\mu \mathrm{m}$.

Chemistry - No lichen substances detected by TLC.

Ecology - The species is found growing on the bark of Lannea coromandelica (Houtt.) Merr. in the University Campus.

Distribution - India (Sikkim), Netherland.

Species examined - INDIA: Assam, Kokrajhar district, Bodoland University Campus, on Lannea coromandelica (Houtt.) Merr. 05/04/2018, J. P. Goswami \& R. Daimari, 2018-0043, Department of Botany, (BU) Kokrajhar, Assam.

Comment - New record to Assam. 
Thallus crustose, corticolous, corticate, endophloeodal to epiphloeodal, dark green, glossy, smooth, continuous to verruculose, mainly non-rimose. Ascomata conspicuous, disc with columella visible from above. Hymenium not inspersed, epihymenium hyaline, with greyish or brownish granules. Collumellar structures well developed in mature ascomata, entire, rarely complex, usually brown to slightly carbonised, rarely strongly carbonised, usually covered with a thick layer of greyish granules. Asci 6-spored, ascospores hyaline, transversely 6-8 septate, amyloid, 50-120 x 10-18 $\mu \mathrm{m}$.

Chemistry - Stictic acid.

Ecology - The species is found growing on the bark of a tree in Ultapani Forest Rangeand the University campus.

Distribution - India (Arunachal Pradesh, Kerala, Andaman and Nicobar Island, Western Ghats, Eastern Himalaya, Karnataka, Meghalaya), Thailand.

Species examined - INDIA: Assam, Kokrajhar district, Ultapani Forest Range on bark of a tree, 23/02/2017, S. Basumatary, P. Islary \& R. Daimari, 2017-0032, Bodoland University campus on the bark of a tree, 26/02/2018, J. P. Goswami, 2018-0036, Department of Botany, (BU) Kokrajhar, Assam.

Comment- New record to Assam

Porina belanospora (Nyl.) Müll. Arg., Bot. Jahrb. Syst. 6: 400, 1885

Fig. 8

Thallus crustose, corticolous, smooth, greyish green, glossy, indeterminate, ecorticate. Ascomata concolorous, minute, immersed to slightly emergent, $0.2-0.3 \mathrm{~mm}$ in diam., not constricted at the base. Ostiole pale brown, depressed, ostiolar rim light brown to mostly black. Involucrellum brown, exciple pale yellowish-orange, hymenium studded with crystals. Asci 8-spored, ascospores hyaline, transversely $11-15$ septate, $63-67$ x 4.9-5.6 $\mu \mathrm{m}$.

Chemistry - No lichen substances detected by TLC.

Ecology - The species is found growing on the bark of a tree in a wildlife sanctuary and on the bark of Artocarpus heterophyllus Lam., in a residential area.

Distribution - India (Andaman and Nicobar Island, Arunachal Pradesh, Maharashtra, Karnataka, Kerala, Meghalaya, West Bengal), New Zealand, Colombia.

Species examined - INDIA: Assam, Kokrajhar district, Chakrashila wildlife sanctuary, on the bark of a tree, 17/02/2017, P. Islary \& S. Basumatary, Pakriguri, on Artocarpus heterophyllus Lam., 02/07/2018, P. Islary \& S. Brahma, 2018-0054, Department of Botany, (BU) Kokrajhar, Assam.

Comment - New record to Assam.
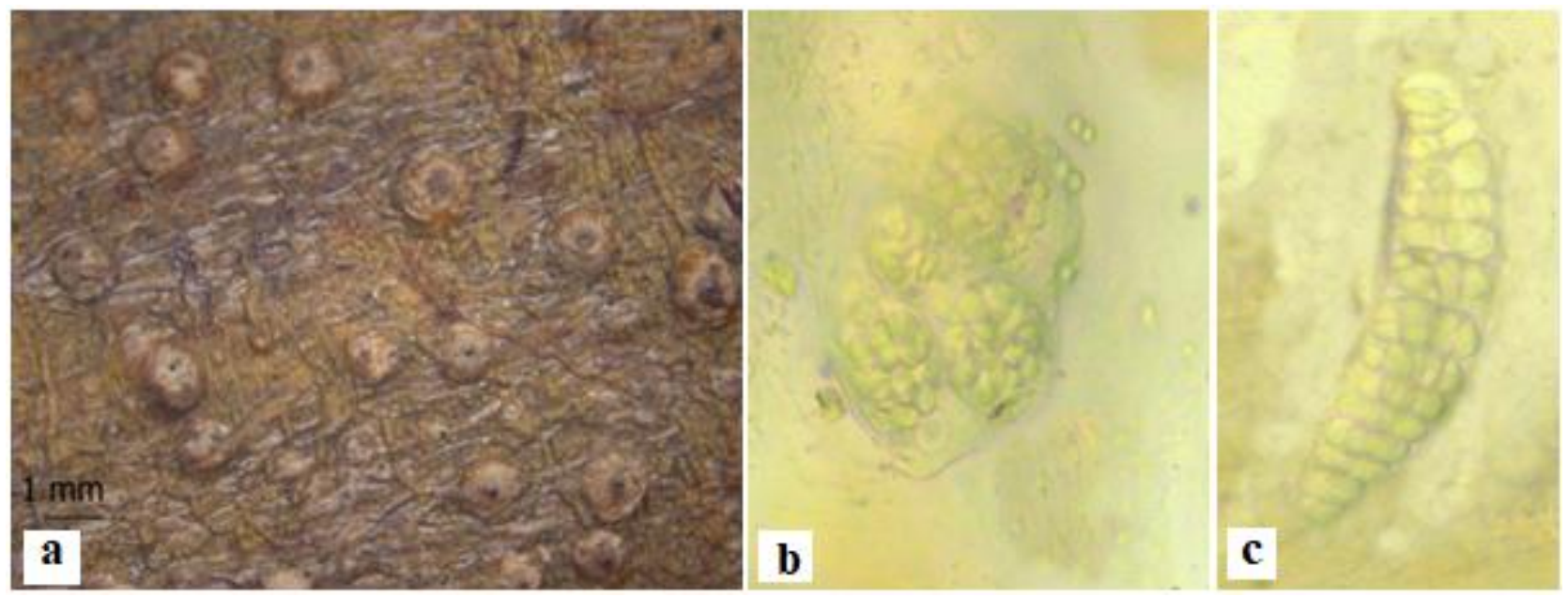

Fig. 3 - Astrothelium alboverrucoides. a Habit. b Ascospores within ascus. c Single ascospore. 

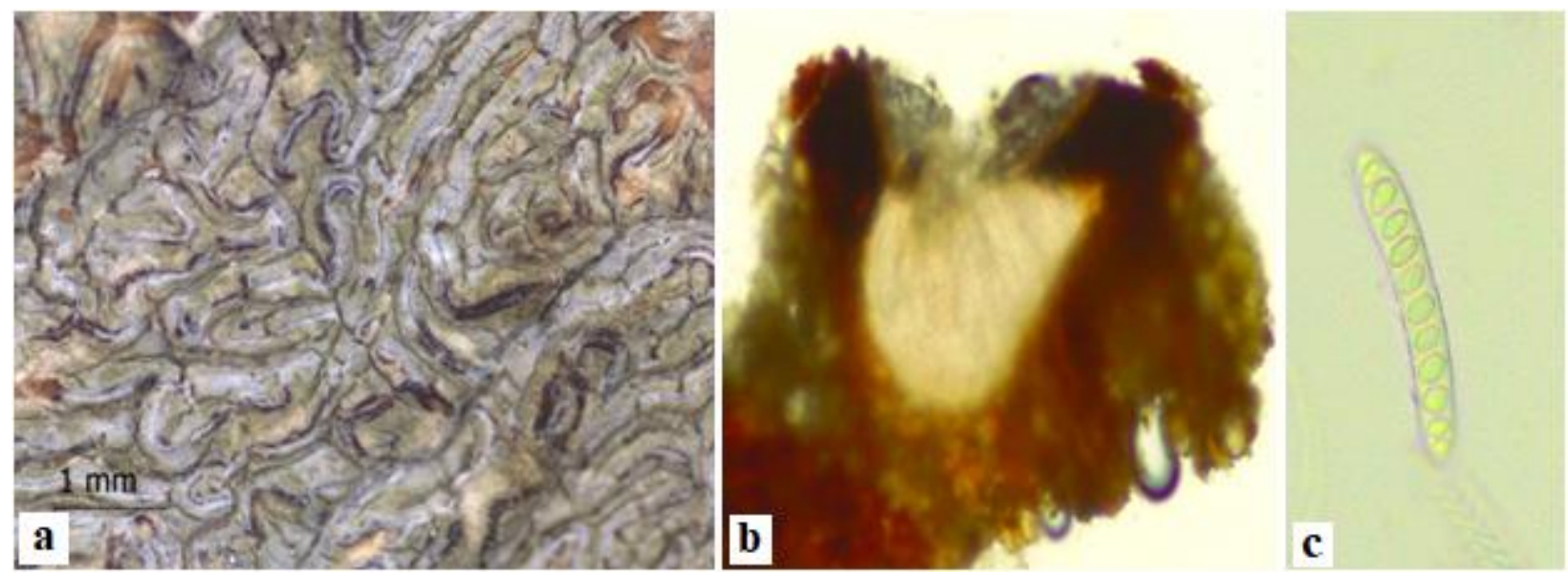

Fig. 4 - Graphis sayeri. a Habit. b VS of apothecia. c Single ascospore.
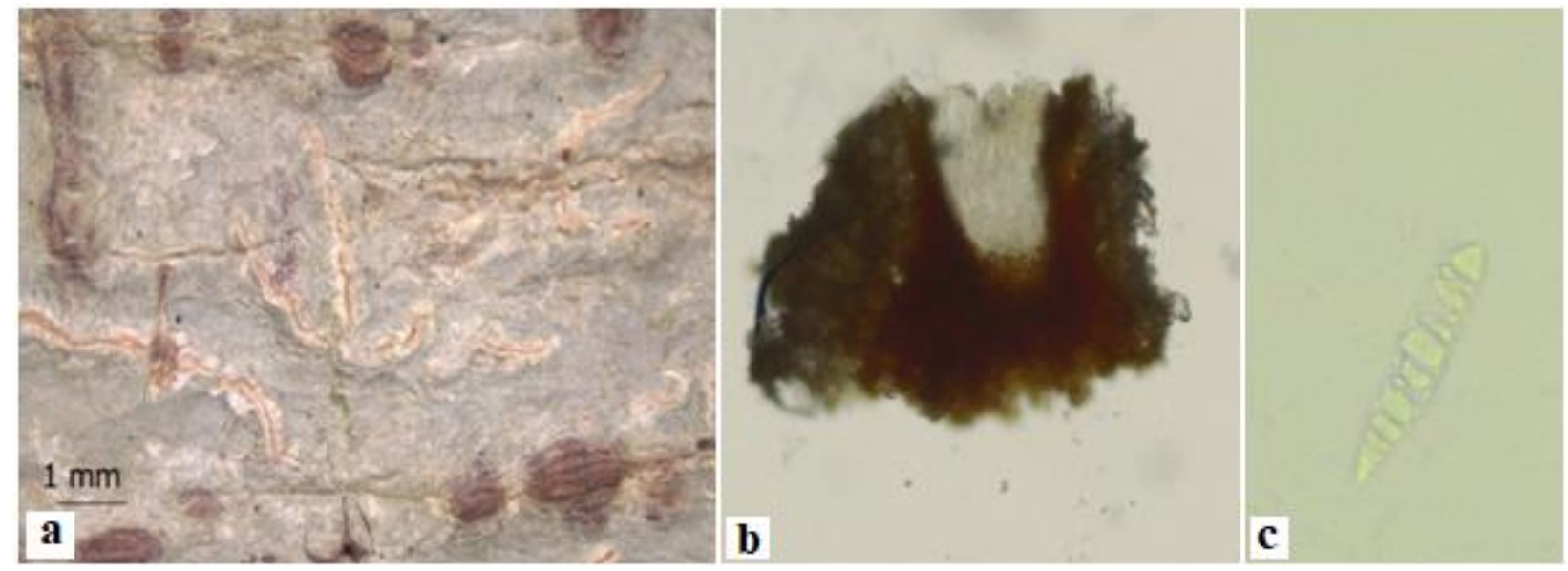

Fig. 5 - Hemithecium croceum. a Habit. b VS of apothecia. c Single ascospore.
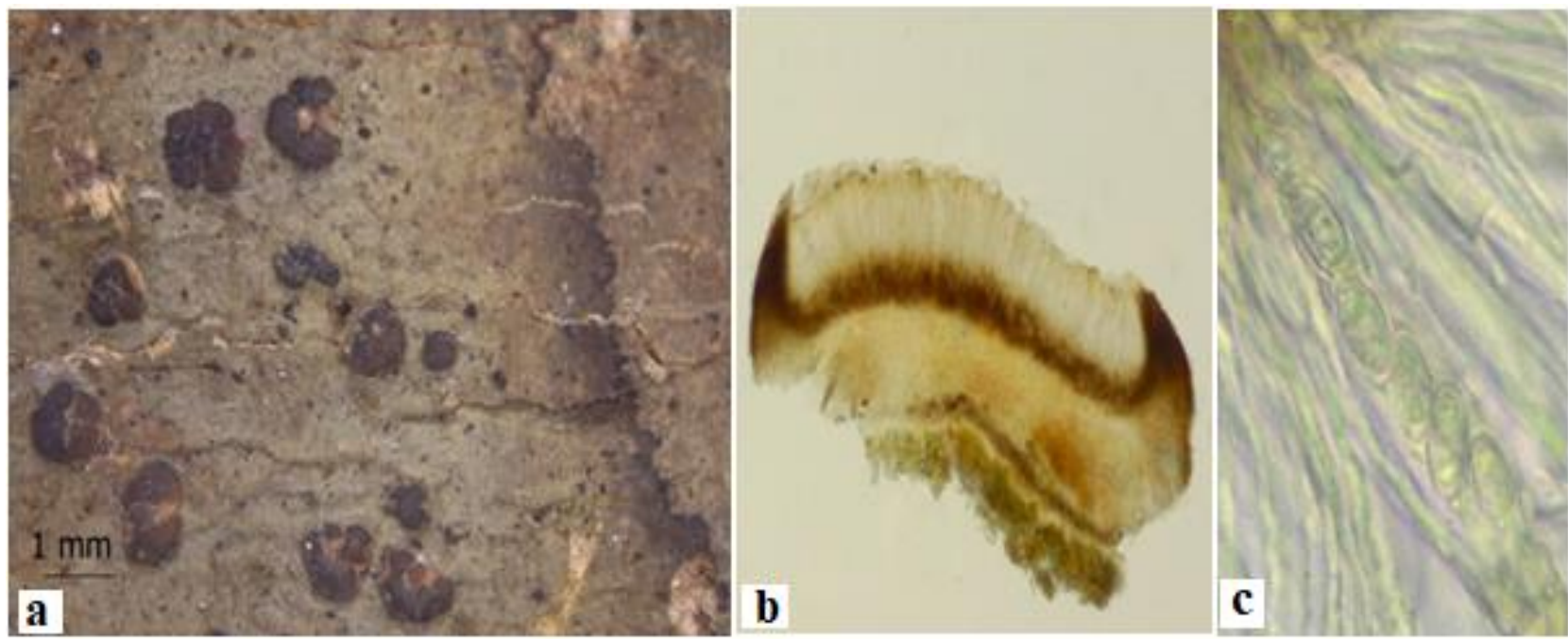

Fig. 6 -Malmidea piperis. a Habit. b VS of apothecia. c Ascospores within acsus. 


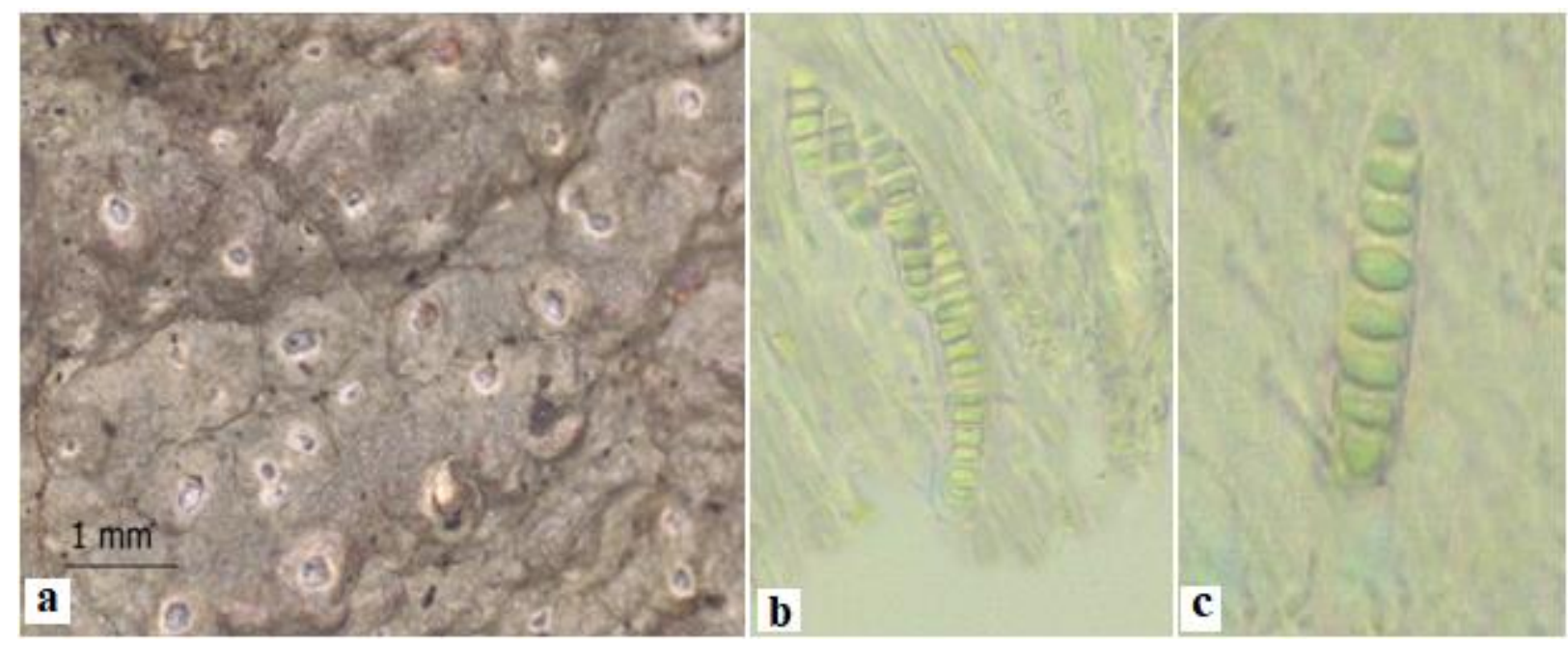

Fig. 7 - Ocellularia allosporoides. a Habit. b Ascospores within ascus. c Single ascospore.

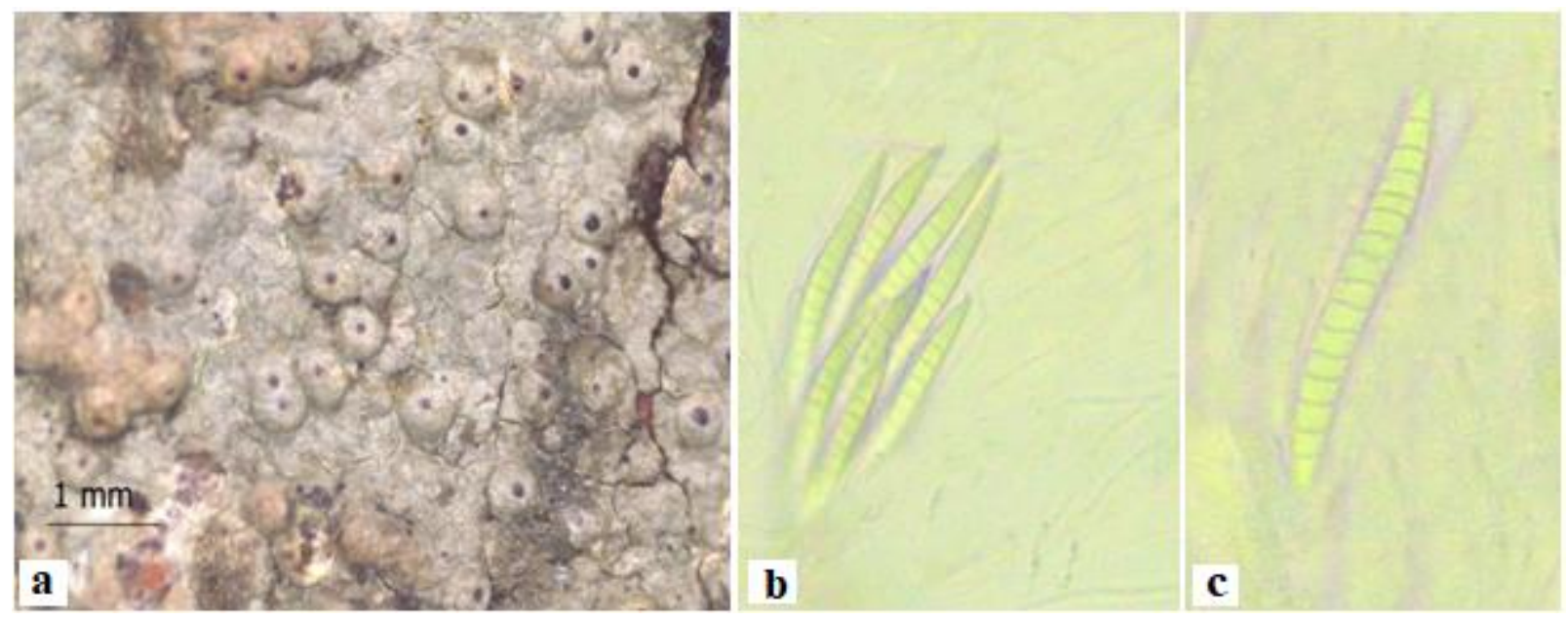

Fig. 8 - Porina belanospora. a Habit. b Ascospores within ascus. c Single ascospore.

\section{Discussion}

The species Astrothelium alboverrucoides is new to India. Only few species of Astrothelium are recorded from India (Singh \& Sinha 2010, Singh et al. 2015, Niranjan \& Sarma 2018). Gupta \& Sinha (2018) recorded A. eustomum from Assam, previously observed by Stirton in 1881 . Five of the species are new additions to the lichen flora of Assam viz. Graphis sayeri, Hemithecium croceum, Malmidea piperis, Ocellularia allosporoides and Porina belanospora. Nine of the species viz. Graphis capillacea, G. chlorotica, G. distincta, G. intermediella, G. subasahinae, Hemithecium croceum, Phaeographis extrusula, P. submarcescens and Porina subhibernica are endemic to India. Species frequently found or having wide distribution are generally preferred for other lichen related studies such as air quality monitoring. Therefore, Dirinaria consimilis, may be employed for such studies in near future.

Literature survey reveals that lichenological work in the region inspite of its biodiversity hotspot is a farcry. The geographical location and climatic conditions of the region is ideal for the colonization of different groups of lichens and seasonal variation influences the visibility, texture, contrast of colours and appearance of fruiting bodies of lichens in all study sites.

\section{Conclusion}

Sporadic collection of lichens from these four sites reveal occurrence of 54 species with one new record from India and five to Assam. This indicates that there are wider scopes of finding more new and interesting species of lichens especially in the northern part of the district. Based on the 
availability of species they can be used for carrying out other lichenological researches such as pollution monitoring studies in the region. From the present study we can conclude that the climatic condition of the region is moderate for lichen growth and it is obvious that extensive exploration of the region for lichens may further produce much more interesting findings and more additions to the lichen flora of India. It will provide baseline information of floristic data regarding the lichen flora of Assam, particularly of the region studied.

\section{Acknowledgements}

The authors are grateful to the Director CSIR-NBRI, Lucknow for permitting two of the authors (PI \& SB) to visit the institute and for providing infrastructure facilities, to Dr. D.K. Upreti for his continuous support and encouragement, authorities of Departments of Botany and Biotechnology, Bodoland University, Kokrajhar, Assam for providing laboratory facilities and various supports related to the present study.

\section{References}

Aptroot A, Lücking R. 2016 - A revisionary synopsis of the Trypetheliaceae (Ascomycota: Trypetheliales). The Lichenologist 48(6), 763-982.

Aptroot A. 2012 - A world key to the species of Anthracothecium and Pyrenula. The Lichenologist 44(1), 5-53.

Awasthi DD. 1991 - A key to the Microlichens of India, Nepal, Sri Lanka. Bibliotheca Lichenologica $40,1-136$.

Awasthi DD. 2007 - A compendium of the Macrolichens from India, Nepal, Sri Lanka. $1^{\text {st }}$ ed. Bishen Singh Mahendra Pal Singh, Dehra Dun, India.

Awasthi DD, Singh KP. 1973 - A note on the revision of some graphidaceous lichen taxa. Current Science 42(18), 656-657.

Daimari R, Hazarika N, Houqe RR, Upreti DK, Nayaka S. 2014 - New records of epiphytic lichens from three districts of Assam. The Indian Forester 140(8), 807-811.

Gupta N, Gupta V, Dwivedi SK. 2016 - New addition to lichen flora of Uttar Pradesh, India. Tropical Plant Research 3(1), 153-156.

Gupta P, Sinha GP. 2011 - A new record of lichen in the genus Graphis for India from Assam. Indian Journal of Forestry 35(1), 133-134.

Gupta P, Sinha GP. 2016 - A first note on foliicolous lichens of Assam, India. Journal of Threatened Taxa 8(7), 9014-9023.

Gupta P, Sinha GP. 2018 - Lichen Flora of Assam. $1^{\text {st }}$ ed. Bishen Singh Mahendra Pal Singh, Dehra Dun, India.

Jayasiri SC, Hyde KD, Ariyawansa HA, Bhat J et al. 2015 - The Faces of Fungi database: fungal names linked with morphology, phylogeny and human impacts. Fungal Diversity 74(1), 3-18.

Joshi S, Upreti DK, Divakar PK, Lumbsch HT, Lücking R. 2018 - A re-evaluation of the lotremoid Graphidaceae (lichenized Ascomycota: Ostropales) in India. The Lichenologist 50(6), 627678.

Kekuda PTR, Raghavendra HL, Vinayaka KS. 2017 - Antimicrobial activity of Heterodermia incana (Stirt.) D.D. Awasthi. International Journal of Green Pharmacy 11, 568-574.

Lücking R, Archer AW, Aptroot A. 2009 - A worldwide key to the genus Graphis (Ostropales: Graphidaceae). The Lichenologist 41, 363-452.

Nayaka S. 2014 - Methods and techniques in collection, preservation and identification of lichens in Plant Taxonomy and Biosystematics. New India Publishing Agency. New Delhi, India, pp.101-128.

Niranjan M, Sarma VV. 2018 - New records of lichenized fungi in the family Trypetheliaceae from Andaman Islands, India. Current Research in Environmental and Applied Mycology 8(4), 438445 . 
Orange A, James PW, White FJ. 2001 - Microchemical Methods for the Identification of Lichens. $1^{\text {st }}$ ed. British Lichen Society, London.

Pant G, Upreti DK. 1993 - The lichen genus Diploschistes in India and Nepal. The Lichenologist 25(1), 33-50.

Rout J, Das P, Upreti DK. 2010 - Epiphytic lichen diversity in a Reserve Forest in Southern Assam, Northeast India. Tropical Ecology 51, 281-288.

Rout J, Rongmei R, Das P. 2005 - Epiphytic lichen flora of a pristine habitat (NIT campus) in Southern Assam, India. Phytotaxonomy 5, 117-119.

Santesson R. 1952 - Foliicolous lichens 1. A Revision of the taxonomy of the obligately foliicolous lichenized fungi. Symb. Bot. Upsal. 12(1), 1-590.

Shivanna R, Garampalli RH. 2014 - Efficacy of lichen extracts as biocontrol agents against Fusarium oxysporum F. Sp. Capsici. Advances in Applied Science Research 5, $273-277$.

Shivanna R, Garampalli RH. 2016 - Investigation of macrolichens for antifungal potentiality against phytopathogens. Indo American Journal of Pharmaceutical Research 6, 5290-5296.

Sinha GP, Ram TAMJ. 2020 - An overview of the current status of lichen diversity in India and identification of gap areas (Abstract), International Symposium on Plant Taxonomy and Ethnobotany. Botanical Survey of India, Kolkata.

Sinha GP, Gupta P, Ram TAMJ, Solanki CM. 2013 - A contribution to the lichen flora of Assam, India. Indian Journal of Forestry 36(3), 393-400.

Singh KP, Sinha GP. 2010 - Indian Lichens: An annotated Checklist. Bishen Singh Mahendra Pal Singh, Dehradun, India.

Singh P, Singh KP, Bhatt AB. 2015 - Diversity and distribution of microlichens in the state ofArunachal Pradesh, Eastern Himalaya, India. Check List 11(6), 1807.

Singh KP, Singh P, Sinha GP. 2018- Lichen diversity in the Eastern Himalaya biodiversity hotspot region, India. Cryptogram Biodiversity and Assessment Special volume, 71-114.

Soundararajan S, Shanmugam P, Nagarajan N, Palanisamy D, Ponnusamy P. 2019 - In vitro study on screening antimicrobial and anti-oxidant potential of Ramalina fastigiata. Journal of Drug Delivery \& Therapeutics 9(1), 216-219.

Stirton J. 1881 - On the vegetable parasites of the tea plant, more especially of Assam. Proceedings of Royal Philosophical Society of Glasgow 13, 181-193.

Stocker-Wörgötter E. 2008 - Metabolic diversity of lichen-forming ascomycetous fungi: culturing, polyketide and shikimate metabolite production, and PKS genes. Nat Prod Rep 25, 188-200.

Zambare VP, Christopher LP. 2012 - Biopharmaceutical potential of lichens. Pharmaceutical Biology 50, 778-798. 